\title{
THE PATENTABILITY OF BIOTECHNOLOGICAL INVENTIONS IN THE EU: AN IMPACT ON THERAPEUTIC PRACTICE
}

DOI: 10.36740/WLek202008129

\author{
Tetyana V. Komarova \\ YAROSLAV MUDRYI NATIONAL LAW UNIVERSITY, KHARKIV, UKRAINE
}

\begin{abstract}
ABSTARCT
The aim: To identify the spheres in which it is forbidden to patent the results of medical researches and as a consequence there is no legal protection of biotechnological inventions. Materials and methods: The research material is a modern European regulatory framework that establishes the basic principles for patentability of biotechnological inventions. The methods of information retrieval, analysis, systematization, and generalization were used in this article.

Conclusions: The Court of Justice has categorically stated that inventions that use human embryonic cells cannot be used for industrial or commercial purposes and therefore cannot be patented. In connection with this prohibition, the Court of Justice provided a unified definition of "embryo" and determined that it could be considered a dividing human egg, but only if it had a real ability to develop into a human. That is, the determining factor is not the beginning of the process of cell proliferation, but their real ability to become human. These decisions have become crucial for the development of research and the use of their results in therapeutic activities in the EU.
\end{abstract}

KEY WORDS: human embryo, EU patent, biotechnology, legislation

Wiad Lek. 2020;73(8):1747-1751

\section{INTRODUCTION}

The problems of bioengineering development and the use of its results in medicine has now become extremely important due to the powerful development of modern technologies and their capabilities. At the same time, this issue cannot be attributed purely to the field of medicine, as it is also closely related to the ethical, social, economic and, of course, legal spheres. If we talk about the legal side of the issue, it is impossible not to touch the topic of patenting the results of bioengineering. Patenting the results of bioengineering has begun to form a new vector in scientific research. If earlier the scientific research of cells of organisms, including human ones, was based on openness and access of the whole scientific community to their course and results, now it has become a commercialized and monetized direction. The difficulty in understanding this issue is compounded by the fact that the use of living cells in research remains an area in which there is no consensus among states $[1,2]$.

\section{THE AIM}

The aim of the research is to identify the spheres in which it is forbidden to patent the results of medical researches and as a consequence there is no legal protection of biotechnological inventions. More over the author has the aim to outline some trends in the development of legal regulation of bioengineering.

\section{MATERIALS AND METHODS}

The research material is a modern European regulatory framework that establishes the basic principles for patent- ability of biotechnological inventions. There have been applied universal, general scientific and special legal methods. The methods of information retrieval, analysis, systematization, and generalization were used in this article. In addition the comparative method was used to investigated differences of legal regulations in different countries.

\section{REVIEW AND DISCUSSION}

One of the first and illustrative cases of patenting the results of mammalian research was the case of the so-called "Onco mouse" or "Harvard mouse", which was a transgenic mouse and was developed for cancer research at Harvard College. Applications for a patent for the invention of the onco mouse were filed in the United States, Europe and Canada. In Canada, the patent was granted, although it was accompanied by a high-profile lawsuit that reached the Supreme Court of Canada. In Europe, namely the European Patent Office, a patent for this invention was issued in 1985, although 20 years later this decision was challenged precisely because of the ethical and moral side of this process and its contradictions to public order (ordre public). Nevertheless, the European competent authorities did not find grounds for revoking the patent, as the 1973 European Patent Convention excludes the patentability of animal species, but does not exclude the patentability of the animals themselves. Only in 2006 the patent was revoked due to non-payment of registration fees and certain shortcomings in the patenting process.

In 1984, the US Patent and Trademark Office also granted a patent for the Harvard Mouse, but much attention was 
paid to the fact that the invention does not contain human cells or human embryonic cells. This can be interpreted as the fact that the Office drew attention to the problem of patenting inventions related to genetic modification of human cells.

It is clear that the development of genetic engineering is also associated with the use of human biomaterials, which raises an even greater layer of ethical concerns. The European Union, as a powerful supranational entity with broad competence which were granted by Member States, could not stay away from these pressing issues. Thus, the EU has taken a number of measures (both organizational and institutional) to develop legal and ethical standards for biomedicine. For example, a special independent advisory body to the European Commission, the European Group on Ethics in Science and New Technologies (EGE), was set up in 1991 to advise EU institutions on bioethics and ethics in science. Also in 1998, the European Parliament and the Council of the EU adopted Directive 98/44 on the legal protection of biotechnological inventions, which provided some answers to questions that arose in practice [3]. The need for such a Directive was due to the extraordinary growth of bioengineering research in Europe and at the same time the uncertainty of researchers about the possibility of patent protection of their scientific results, as the 1973 European Patent Convention did not provide clear answers to a number of questions.

As the EU positions itself as a democratic player in the international arena, it is significant that the adoption of the Directive was preceded by more than 10 years of negotiations with all stakeholders. And, first of all, these negotiations concerned the ethical side of the possibility of patentability of biotechnological inventions. Thus, the most active participants in these negotiations were the European Parliament as a representative of the people of Europe, who advocated the dominance of ethics over economic interests, and the EGE, which also insisted on this approach. Greenpeace also submitted its position that the possibility of patenting inventions related to genetic engineering is a commercialization of the human body, and therefore has a negative implication.

Directive 98/44 in its Art. 5 enshrined that: " 1 . The human body, at the various stages of its formation and development, and the simple discovery of one of its elements, including the sequence or partial sequence of a gene, cannot constitute patentable inventions. 2. An element isolated from the human body or otherwise produced by means of a technical process, including the sequence or partial sequence of a gene, may constitute a patentable invention, even if the structure of that element is identical to that of a natural element". In addition to Art. 6 of the Directive established that inventions shall be considered unpatentable where their commercial exploitation would be contrary to public policy (ordre public) or morality. This norm is generally accepted [4]. In particular, non-patentable are: human cloning processes, human germline genetic modification processes, use of human embryos for industrial or commercial purposes, processes of altering the genetic identity of animals that may cause their suffering without any significant medical benefit to humans or animals, and also animals that are the result of such processes.

In response to the adoption of the Directive 98/44, the Netherlands brought an action against the European Parliament and the Council for annulment, claiming that it violated human dignity [5]. The Netherlands' claim was also supported by Italy and Norway. The Court of Justice ruled in 2001 that the Directive is not contrary to EU law, as elements of the human body cannot be patented per se. Only inventions that combine a natural element with a technical process that allows the natural element to be isolated or manufactured for industrial use can be the subject of patent protection.

Thus, a part of the human body may be part of a product that is patentable, but in no way by itself. This difference also applies to work on the sequence or partial sequence of human genes. The result of such work can be the basis for the grant of a patent only if the application is accompanied by a description of the original method of sequential actions that led to the invention, as well as an explanation of industrial application. Thus, the protection provided by the Directive applies only to the results of inventive, scientific or technical work and extends to biological data that exist in their natural state and can be applied in industry.

Unfortunately, this decision of the Court of Justice did not answer many questions, as there were still inconsistencies with the provision of paragraph 42 of the Directive's Preamble, which states that uses of human embryos for industrial or commercial purposes must be excluded from patentability, but at the same time such exclusion does not affect inventions for therapeutic or diagnostic purposes which are applied to the human embryo and are useful to it.

The inconsistency concerns the fact that there is no unified definition of such a term as «human embryo». Due to different national laws in Europe, there is a significant difference in the understanding of this term in the EU Member States. Thus, in the UK, an embryo is a live fetus whose fertilization process is complete (when two cells have emerged), including the egg during fertilization. In Spain, a distinction is made between pre-embryonic, embryonic and fetal conditions. Up to 14 days, the set of cells is considered pre-embryo, from 14 days to 2.5 months - the embryo, after - the fetus. In Germany, an embryo is a fertilized human egg that can develop from the moment the cell nucleus fuse. Providing a uniform definition of the embryo is a rather controversial issue, as it is difficult to say whether this can be attributed to the EU competence.

The wording of the Directive also completely ignores the fact that modern reproductive medicine has the ability to manipulate human eggs and sperm that are not regarded as cloning or as an intervention in the human embryo, and therefore patent applications for the use of human germ cells under the Directive may be granted as patents for parts of the human body. The possibility of patenting the results of such activities clearly hinders the activities of doctors and limits the access of both doctors and bioengineering developers to the information they may need to save patients' lives. 
An example of this is the patents of the American company Myriad for the so-called "breast cancer gene (BRCA1)", which is considered responsible for the hereditary form of breast cancer. These patents have also been validated and obtained in Europe and their subject are, for example: gene sequence for breast cancer gene in all variations and mutations, encoded proteins, use of gene sequences for diagnosis, use of gene sequences for therapy, use of gene sequences for testing new drugs, all cells into which the gene can be transferred. The company that first patented the gene sequence may prohibit the use of this information by other entities, and thus block medical practices and developments in this area. In this regard, in 1997 the Senate Committee of the German Research Group (DFG) expressed its position that the patentability of such processes affects the freedom of choice of doctors and the exclusion of the possibility of obtaining patents is ethically justified.

A rather significant step in the interpretation of the Directive was the ruling of the Court of Justice in 2011 in the Brüstle case, which concerned the interpretation of Art. 6 (2) of the Directive [6]. The circumstances of the case were that in 1997 the German neurologist Brüstle applied for a patent for the invention of isolation and purification of neuronal cells taken from embryonic stem cells. It has been claimed that the present invention can be used for therapeutic purposes, for example, in the fight against Parkinson's disease. Greenpeace appealed the patent and the German Federal Patent Court annulled the patent, which was challenged by Dr. Brüstle in the German Federal Court. In 2010 The Federal Patent Court of Germany in turn sent a preliminary request to the Court of Justice for an interpretation of Art. 6 (2) (c) of the Directive in the part of the prohibition of the "uses of human embryos for industrial and commercial purposes". In its judgment, the Court of Justice stated that the patenting of human embryonic stem cells is a violation of the right to human dignity.

The Court of Justice has ruled that the definition of «embryo» should be interpreted autonomously and in a uniform manner in relation to all EU Member States. The lack of a single definition of the human embryo risks the authors of some biotechnological inventions to patent them in the Member States that have the narrowest concept of the human embryo and are the most liberal in terms of patenting, while in other Member States these inventions cannot be patented. This situation will negatively affect the smooth functioning of the EU internal market. The Court emphasized that, although the concept of the human embryo is a very sensitive social issue in many Member States, reflecting traditions and value systems, it should provide an appropriate definition, limiting itself to a legal interpretation of the provisions of the Directive.

Taking into account that the Directive provides that the human body at different stages of its formation and development cannot be a patented invention, the Court has given a very broad interpretation of the definition of embryo. Accordingly, any human ovum must, once fertilized, be regarded as a "human embryo" within the meaning and for the purposes of Article 6 (2) (c) of the
Directive, since such fertilization is the beginning of the process of human development. Also, a "human embryo" is an unfertilized human egg into which a cell nucleus has been transplanted from a mature human cell, as well as any unfertilized human egg whose division and further development is stimulated by parthenogenesis. That is, an embryo is any human egg that divides and is able to begin the process of human development.

It has become extremely important for the scientific medical community that the prohibition of the use of human embryos also extends to such patenting for the scientific purposes. The use of human embryos in inventions could be patentable only for therapeutic or diagnostic purposes. Moreover the invention in which embryonic stem cells have been used could not be patented, since the embryo is destroyed in order to extract them, and this is also contrary to the right to human dignity.

The decision provoked a stormy reaction among EU Member States because as noted above, there are significant differences between states regarding the definition of «embryo». The European Court of Human Rights also spoke about this, emphasizing that a broad consensus has not yet been reached on this issue, and the limits of the state's discretion on this issue should be quite wide $[7,8,9]$. The scientific community also reacted violently to the ruling of the Court of Justice and even sent letters to the Court explaining that stem cells could be taken not from viable embryo, but from bio-material that is intended for disposal [see 10,11]. The Court of Justice took responsibility and entered the territory, which has not been entered before. No judicial body has tried to harmonize and propose a single European standard for approaching the timing of beginning of human life [see 12].

The result of this decision of the Court of Justice is obvious - a significant slowdown in scientific progress in the field of genetic engineering, which is aimed at drug development. Indeed, the Directive does not prohibit the use of human embryos in the context of scientific research as it regulates only the issue of patenting biotechnological inventions. But it is clear that for scientists and medical practitioners patenting their invention is logical and facilitates their work. Therefore, in this sense the decision of the Court of Justice clearly does not promote the development of research of stem cells in the EU, as each time they have to prove the existence of therapeutic or diagnostic objectives of the research. In practice, this is a rather difficult task, so many laboratories will move their facilities outside the EU, for example, to China or the United States [see 13]. Moreover, in the United States there is no morality clause in patent law and all attempts to limit the patentability of bioengineering inventions at the legislative level have failed [14], so the field for research and legal protection of its results is more attractive to medical scientists.

Further development took place with the Court of Justice ruling in 2014 in the case of International Stem Cell Corporation, where International Stem Cell Corporation wanted to patent in the UK the invention of a process in which a human egg is activated by various chemical and 
electrical methods and it can grow into a blastocyst phase (approximately 200-300 cells after cell division), but it is unable to develop further because it lacks the parental DNA needed to form the placenta. Based on the Brüstle decision, the present invention is not patentable as it also falls under the too broad definition of 'embryo' given by the Court of Justice.

But in International Stem Cell Corporation decision, the Court of Justice clarified that an «embryo» can be considered an unfertilized human egg, the division and further development of which is stimulated by parthenogenesis, if it «has the inherent ability to develop into a human» [15]. And here it is important not the beginning of the process of cell proliferation, but their ability to become a human. The question of when this possibility arises should be decided by national courts and it is they who may prohibit the patenting of relevant inventions in matters of public order and morality. It is clear that it is not possible to achieve a uniform attitude of the courts of all Member States, as this position will depend on the traditions of the EU Member State. It can be predicted that, for example, in Poland the courts will be inclined to deny the patenting of inventions of processes related to parthenogenesis, and in more liberal states on this issue - to allow. Such different approaches can lead to a violation of the freedoms of the EU common market. By the way, in the UK, the competent authority after a preliminary ruling by the Court of Justice granted a patent to the International Stem Cell Corporation.

After the decision in the case of International Stem Cell Corporation it can be stated that the role of courts in matters of ethics and morality has become quite significant [see $16,17,18]$. In this regard, the process of harmonization of judicial activities within the EU needs considerable attention, as medicine is the area covered by EU freedoms. This was brought to the attention of the European Commission in 2018 as well, and it addressed a formal request to the EGE, which is currently developing a conclusion on the ethics of gene editing. This conclusion will analyze the ethical, societal, fundamental rights of genome editing programs in humans, animals and plants, as well as a set of policy recommendations for EU Member States. These recommendations will harmonize (namely, harmonize, not unify) the approaches of doctors-researchers on these issues. European researchers have repeatedly drawn attention to this $[19,20]$.

\section{CONCLUSIONS}

It is investigated that for the first time an international judicial body has provided an interpretation of the term "embryo", despite the fact that the national laws of the EU Member States contain different definitions of this term. Providing a uniform definition of an embryo is a rather controversial issue, as it is difficult to say whether it can fall within the competence of the EU. But the Court of Justice itself has recognized that it has jurisdiction to determine the limit that can be considered the beginning of human life. The Court has categorically stated that inventions that use human embryonic cells cannot be used for industrial or commercial purposes and therefore cannot be patented. In connection with this prohibition, the Court of Justice provided a unified definition of "embryo" and determined that it could be considered a dividing human egg, but only if it had a real ability to develop into a human. That is, the determining factor is not the beginning of the process of cell proliferation, but their real ability to become human. These decisions have become crucial for the development of research and the use of their results in therapeutic activities in the EU.

The International Stem Cell Corporation decision is a move towards a smarter approach to patenting inventions using human stem cells. However there is not uniformity and hence there are certain difficulties for regenerative medicine and cell therapy in the EU. Therefore, both lawyers and physicians should compete for the development of treatment based on pluripotent stem cell technology.

\section{REFERENCES}

1. Schwartz R.M, Minssen T. Life after Myriad: the uncertain future of patenting biomedical innovation and personalised medicine in an international context. Intellectual Property Quarterly. 2015; 3:189-241.

2. Baeyens A, Goffin T. European Court of Justice: case (-364/13, International Stem Cell Corp v Comptroller General of Patents, Designs and Trade Marks. European Journal of Health Law. 2015; 22(2):141-164.

3. Directive 98/44/EC of the European Parliament and of the Council of 6 July 1998 on the legal protection of biotechnological inventions. Official Journal. L. 213, 30.7.1998: 13-21.

4. Min Y. Morality - an equivocal area in the patent system. European Intellectual Property Review. 2012; 34(4): 261-265.

5. Judgment (-377/98, Netherlands v Parliament and Council. European Court Review: I - 7149 .

6. Judgment $(-34 / 10$, Oliver Brüstle $v$ Greenpeace. http://curia.europa.eu/juris/document/document. jsf?text $=\&$ docid $=111402 \&$ pagelndex $=0 \&$ doclang $=$ EN\&mode $=$ Ist\&dir $=\& 0 c c=$ first\&part $=1 \& c i d=3312047$

7. Case H v Norway, ECHR Judgement, 19/05/1992. HUDOC. European Court of Human Rights. URL: https://hudoc.echr.coe.int/ eng\#\{\%22itemid\%22:[\%22001-1759\%22]\}

8. Case Vo v France, ECHR Judgement, 8/07/2004. HUDOC. European Court of Human Rights. URL: https://hudoc.echr.coe.int/eng-press\#\{\%22ite mid\%22:[\%22003-1047783-1084371\%22]\}

9. Case Evans v the United Kingdom, ECHR Judgement, 7/03/2007. HUDOC. European Court of Human Rights. URL: https://hudoc.echr.coe.int/ eng-press\#\{\%22itemid\%22:[\%22001-72684\%22]\}

10. Sideri K. Bioproperty, Biomedicine and Deliberative Governance: Patents as Discourse on Life. 2014: 79, 80.

11. Austin S. No to Ban on Stem-Cell Patents. Nature. 2011; 472 (7344): 418.

12. Faeh A. Judicial activism, the Biotech directive and its institutional implications - is the CJEU acting as a legislator or a court when defining the "human embryo"? European Law Review. 2015; 4:613-627.

13. Yuen-Ting Wong A, Mahalatchimy A. Human stem cells patentsEmerging issues and challenges in Europe, United States, China, and Japan. The Journal of World Intellectual Property. 2018:1-30.

14. Nordberg A, Minssen T. A'Ray of Hope' for European Stem Cell Patents or'Out of the Smog into the Fog'?: An Analysis of Recent European Case Law and How It Compares to the US. International Review of Intellectual Property and Competition Law. 2016: 160. 
15. Judgment (-364/13, International Stem Cell Corporation v Comptroller General of Patents, Designs and Trade Marks. para. 28: http://curia.europa.eu/juris/document/document. jsf?text $=\& d o c i d=160936 \&$ pagelndex $=0 \&$ doclang $=$ en\&mode $=\mid s t \& d i r=\& o c c=$ first $\&$ part $=1 \& c i d=232540$

16. Molnar-Gabor F. Science, ethics, and patents. Ethicaly-Motivated Barriers to the Patenting of the Results of human embryonic stem cell research. In: The Matrix of Stem Cell Research: an Approach of Rethinking Science in Society ed. by Hauskeller Ch., Manzeschke A., Pichl A. Routledge, 2019, p. 50-67.

17. Bonadio E. Biotech Patents and Morality after Brustle. European Intellectual Property Review. 2012; 34 (10): 433-443.

18. Brack H.P. Post Brüstle Developments in EU Biotech Patent Law at the CJEU. Epi Information. Vol. 1, P, 20-25: https://information.patentepi. org/1-16/post-bruestle-developments.html

19. Aerts R. The unitary patent and the biotechnology directive: is uniform protection of biotechnological inventions ensured? European Intellectual Property Review. 2014; 36(9): 584-587.

20. McMahon A. An institutional examination of the implications of the unitary patent package for the morality provisions: a fragmented future too far? International Review of Intellectual Property and Competition Law. 2017; 48(1): 42-70,
ORCID and contibutionship:

Tetyana V. Komarova: 0000-0002-7663-3264 ${ }^{A, B, D, E, F}$

\section{Conflict of interest:}

The Author declare no conflict of interest.

\section{CORRESPONDING AUTHOR}

\section{Tetyana V. Komarova}

Yaroslav Mudryi National Law University

Pushkinska str, 77, 61024, Kharkiv, Ukraine

tel: +380505705562

e-mail:t.v.komarova@nlu.edu.ua

Received: 18.04 .2019

Accepted: 01.07.2020

A - Work concept and design, B - Data collection and analysis, C - Responsibility for statistical analysis, D - Writing the article, E - Critical review, F - Final approval of the article 